Journal of Environmental Science and Public Health

doi: 10.26502/jesph.96120020

Volume 1, Issue 4

Research Article

\title{
Assessing Bioaccumulation in Earth Worms
}

\author{
$\mathrm{Ujah} \mathrm{II}^{1^{*}}$, Onwurah INE ${ }^{2}$, Ubani $\mathrm{SC}^{3}$, Okeke $\mathrm{DO}^{4}$ and Okpashi $\mathrm{VE}^{5}$ \\ ${ }^{1}$ Department of Biochemistry, University of Nigeria, Nsukka, Nigeria
}

*Corresponding Author: Ujah II, Department of Biochemistry, University of Nigeria, Nsukka, Nigeria, E-mail: ujahii812f@gmail.com

Received: 02 September 2017; Accepted: 20 September 2017; Published: 06 October 2017

\begin{abstract}
Various concentrations of lead (II) tetraoxosulphate (VI) were prepared by dissolving $1 \mathrm{~g}, 1.5 \mathrm{~g}, 2 \mathrm{~g}$ and $3 \mathrm{~g}$ of the salt in deionized water and making up to volume to100 $\mathrm{ml}$. Soil samples were prepared and allowed to equilibrate with the different concentrations of the salt samples. After equilibration, earthworm species which had been acclimatized to the in-situ environment were introduced the equilibrated soil samples. The earthworms were allowed to stay between 3-5 days in the soil samples. They were harvested and the lead (II) tetraoxosulphate (VI) content of the earthworm samples. The result showed that the earthworms possessed the ability to bioaccumulate the salt samples and the statistical analysis showed increase in bioaccumulation with increase in the salt content.
\end{abstract}

Keywords: Earthworm; Lead (II) tetraoxosulphate (VI); Protein; Carbohydrate; Atomic Absorption Spectrophotometer

\section{Introduction}

Lead is a group (IV) heavy metal that occurs naturally and is generally mined from its ores [1]. It has different application and uses such as in ceramic products, paints, as a shield against radioactive rays and other various applications. Lead is transported through eating food contaminated with lead, working places, health care products and hobbies. Industrialization, urbanization and the use of leaded product increases the deposition of lead on land, lake ponds leading to environmental pollution with effects on human health [2]. Lead accumulation causes physiological perturbations [3]. The deleterious effects of lead is due to the fact that human do not metabolize lead, thus they accumulate in the body tissues they exert some effects such as nervous system disorder. Bioaccumulation, 
biovailability and deposition of lead in an area could be assessed using earthworm [4]. There are about nineteen species of earthworm which has been described as the intestines of the soil (Aristotle $330 \mathrm{BC}$ ). Among these species of earthworm, the species most commonly used for bioaccumulation studies is Lumbriculus Variegatus [5-7]. The use of any species of earthworm in bioaccumulation studies is dependent on the ease of culture, chemical exposure history, adequate tissue mass for chemical analysis, tolerance to a wide range of chemicals, physiochemical characteristics, low sensitivity to contaminants and amenability to long term exposure [8]. The uptake of chemicals and heavy metals in earthworm is by passive diffusion driven by the fugacity difference between the earthworm and organism tissue. Earthworm is a common representative of the soil macro fauna thus the use in bioaccumulation studies. Bioaccumulation testing of heavy metal involving earthworms is a simple procedure in which earthworm is exposed to spiked soil for a given period after which the earthworm is harvested from the soil and analyzed for contaminant of interest. Some physiological parameters have also been noted to signal bioaccumulation [9] and relevant in this study is the total carbohydrate and protein. Earthworm apart from its use in bioaccumulation studies has also been used to break down organic residues such as sewage sludge, animal waste, industrial waste [10].

\section{Material and Methods}

Earthworm and soil samples were obtained from Obukpa, in Nsukka Enugu State Nigeria in the from moist soil sample. The soil analysis was carried was carried out according to the method of Vogel (1965). Lead tetraoxosulphate (vi) of concentrations: $1 \%, 1.5 \%, 2 \%$ and $3 \%$ were prepared and introduced into $500 \mathrm{~g}$ of the soil samples. After equilibration, the earthworms were rinsed with deionized water and introduced into the spiked soil samples. The earth worms were harvested after incubation period. The accumulated heavy metals in the tissues of the earthworms were determined, the effects of the accumulated heavy metals on the carbohydrate and protein content were also determined.

\section{Results and Discussion}

The result of the soil analysis indicates the absence of lead and that the texture class is loam-sand with about $2 \%$ organic matter content. In all the four salt concentrations, accumulation of the test sample was observed. This agrees with the findings of [11] who had also noted bioaccumulation in their study. The statistical analysis and the results also indicate increase in body's salt metal with increase in salt concentration until the lethal dose. In the preliminary investigation, it was observed that the lethal dose is $5 \%$ in the salt in $500 \mathrm{~g}$ of the soil sample. Lethal dose has also been observed by other authors [12] who noted toxicity with increase in salt concentration. During the research study the earthworms showed avoidance of tonic concentrations by their wriggling movement and the tendency to escape out of the enclosure.

The result of the statistical analysis also show that the concentration from $2 \%$ were significant in the bioaccumulation result. The result shows the ability of earthworms to bioaccumulate the salt samples. Bioaccumulation has been observed in earthworm Lumbriculus variegates [13]. The earthworms also avoided higher concentrations of the salt samples, this they could easily avoid if not in an enclosure. The result of the protein and carbohydrate analysis shows increase in the protein and carbohydrate levels after the introduction of the salt sample. 
[14] in their research on Dendrobaema rubida had also similar observation. Studies on the effect of lead on carbohydrate metabolizing enzymes showed a reduction in the glycogen stores and increase in the activity of carbohydrate metabolizing enzymes suggesting an increase in the carbohydrate level $[15,16]$ which agrees with the result of this work. This study showed a time dependent increase in the carbohydrate concentration which has also been reported by other studies [17]. There was also increase in the protein concentration after the introduction of the lead samples which agrees with the result of [18] (Table 1-3).

\begin{tabular}{|l|l|l|l|l|l|l|l|l|l|l|l|}
\hline $\begin{array}{l}\text { Textural } \\
\text { Class }\end{array}$ & $\begin{array}{l}\% \\
\text { clay }\end{array}$ & $\begin{array}{l}\text { \% } \\
\text { silt }\end{array}$ & $\begin{array}{l}\text { \% } \\
\text { sand }\end{array}$ & $\begin{array}{l}\mathbf{p H} \\
\mathbf{H}_{2} \mathbf{O}\end{array}$ & $\begin{array}{l}\mathbf{0 . 1 N K O L} \\
\mathbf{p H}\end{array}$ & $\boldsymbol{\%} \mathbf{C}$ & $\mathbf{K}$ & $\mathbf{O . M}$ & $\mathbf{\%}$ & $\mathbf{H}$ & $\mathbf{P}$ \\
\hline LS & 6.48 & 7.12 & 66.70 & 7.0 & 6.7 & 0.641 & 5.09 & 1.10 & 0.008 & 3.8 & 130.18 \\
\hline
\end{tabular}

Table 1: Soil Analysis.

\begin{tabular}{|l|l|}
\hline Saltconcentration $(\%)$ & Leadaccumulated $(\mathbf{m g})$ \\
\hline 1 & 0.0045 \\
\hline 1.5 & 0.1202 \\
\hline 2.0 & 0.4718 \\
\hline 3.0 & 0.4005 \\
\hline
\end{tabular}

Table 2: Accumulation of lead tetraoxosulphate (vi) in the earthworms.

\begin{tabular}{|l|l|l|l|}
\hline $\begin{array}{l}\text { Salt } \\
\text { concentrations }\end{array}$ & $\begin{array}{l}\text { Carbohydrate } \\
\text { concentration }\end{array}$ & $\mathbf{N}$ & \% crude protein \\
\hline Control & 0.012 & 0.1051 & 0.6567 \\
\hline $1 \%$ & 0.056 & 0.4102 & 2.5043 \\
\hline
\end{tabular}

Table 3: Effects of accumulation of lead on carbohydrate and protein content.

\section{Conclusion}

In conclusion it could be said that earthworms bioaccumulate heavy metals and could be used in bioremedial studies.

\section{References}

1. Yaw Ababio O. Lead, New school Chemistry Africa publicashers limited. Onistsha Nigeria (1990): 451452.

2. Hacker JH, Bannasch P, Cohembano A. Effect of lead nitrate on liver carbohydrate enzymes and glycogen content in rats. Patolgica Biochmica (1990): 1-2.

3. Racicoot TG, Leviay MC. Blood and liver enzymes in rainbow trout with enphasis on the diagnostic use in the study of carbontrachtoride toxicity and case for Aeromones infection. J. fish Biol 7 (1975): 825-835.

4. Philips DJH. Quatitative Aqutic Biological indicators. Their use to monitor trace metal and organochlorine pollution. Applied science Publisher limited, London (1980). 
5. Schuytetema GS, Krawezt DE, Riffs WL, et al. Comparative uptake of hexachlorobenzene by fathead memows, amphipods and oligochaeta worms from water and sediments. Environ Toxicol chem 7 (1988): 1035-1044.

6. Philips DJH. Quatitative Aqutic Biological indicators. Their use to monitor trace metal and organochlorine pollution. Applied science Publisher limited, London (1980).

7. Brunson EL, Canfield TJ, Duyer EJ, et al. Assessing bioaccumulation of contaminants from sediments from upper Mississippi River using field collected Oligochaetes and laboratory exposed Lumbriculus variegates. Arch Environ contain Toxicol 35 (1998): 191-201.

8. Stanley LJ. Effect of sedimentary organic matter composition on the partisitioning and bioavartabilities of dieldrin to Oligochaeta Lunbriculus variegates.Environ Sc Technol 31 (1997): 2577-2587.

9. Moore MN, Simpson MG. Molecular and cellular pathology in environmental impact assessment. Aquatic toxicology 22 (1992): 313-322.

10. Dominguez J, Edward CA. Effects of stoking rate and moisture. SoilBiology and biochemistry (1997): 74346.

11. Timothy DD, Kelvin GL, Edward NI, et al. The course of metal loss in LubriculusVariegatus following sediment exposure. Setal press 22 (2002): 886-889.

12. Christopher GI, Eric LB, Ning W, et al. Uptake and Depuration of non-ionic organic contaminants from sediments by Oligochaeta Lumbriculus variegates. Setac Press 22 (2002): 872-885.

13. Conrad AU, Comber SD, Simkiss K. New method for assessment of the contaminat uptake routes in Oligochaeta lumbriculusvariegates. Bull Environ Toxico 165 (2000): 16-21.

14. Richard, Ireland. Glycogen-lead relationship in earthworm Dendrobaena rubida. Histochemisry and cell Biology 64 (2004): 465-472.

15. Hacker JH, Bannasch P, Cohembano A. Effect of lead nitrate on liver carbohydrate enzymes and glycogen content in rats. Patolgica Biochmica (1990): 1-2.

16. De Ley J, Vercrusse R. Glucose -6- phosphate and gluconate -6- phosphate dehydrogenase in worms. Biochem.Acta 16 (1955): 615-616.

17. Kumar M, Upreti KR. Impact of lead stress and adaptation in Escherichiacoli. Ecotoxicol environ sat 47 (1986): 246-252.

18. Klana E, Shelton ER. The Effect of lead on the metabolism of nuclear protein which becomes prominent in lead induced inclusion bodies. The American Journal of pathology 160 (2002):1047-1056. 